() A. I. Ivanko, Candidate of Engineering sciences (PhD), Associate professor, O. S. Marchenko, graduate student, Igor Sikorsky Kyiv Polytechnic Institute, Kyiv, Ukraine

\title{
METHOD OF SHEET MATERIAL TRIMMING WITHOUT USING COUNTER-KNIFE
}

\author{
The purpose of this work is to analytically determine \\ the possibility of a new method without using counter-knife \\ of sheet material during its transportation in a rotary cutting \\ section. Consider the pneumatic module counter-knife.
}

Keywords: sheet material; cutting tools; trimming; pneumo-
counter-knife; transportation; processing area; air cushion.

\section{Formulation of the problem}

In modern sheet-cutting machines the trimming method is applied. That is the machine process when the knife cuts a pile of sheets and cuts into the counter-knife at the end of the kinematic cycle. Each cycle of knife motion is accompanied by complex technological processes. Under the effect of significant loading acting on the knife and, especially its hitting at the end of kinematic cycle, an accelerated dulling of its cutting edge appears. This leads to deterioration in the cutting quality and consequently to appearance of the finished product rejects [1].

The method without using counter-knife excludes its applying. This means that knife does not contact the bearing surface of the counter-knife in the process of trimming, but only the sheet material. This increases greatly the durability of the cutting tool its operation $[2,3]$.
Analysis of previous studies

Devices for sheet materials cutting include a leveling system and toothed passing conveyors. The transportation system can consist of a tool unit with fixed cutting tools [4-6]. The sheet material is driven to the cutting area at constant speed $\mathrm{V}_{\mathrm{A}}$ along the transfer table towards the tooling unit. Due to the same direction of drums rotation as well as to interaction between the cutting tool and the counter-knife, it is possible to cut a defined area of the material. Under condition of the step of the cutting tool being equal and $\mathrm{V}_{\mathrm{A}}=\omega \cdot \mathrm{r}=$ const the sheet can be trimmed along a defined line. To provide the shape of the cut, the sheet can move at variable speed $\mathrm{V}_{\mathrm{A}}$.

\section{Purpose of the work}

The purpose of this work is to analytically determine the potentiality of applying a new method without using counter-knife for sheet material during its trans-

(C) $2017 \mathrm{p}$. 
portation in a rotary cutting section as well as to consider the pneumatic module counter-knife.

\section{Presentation of the main material}

The process of transportation of semi-finished products by the pneumatic systems is considered in work [7]. The open-type jet pneumatic conveyor is made in the form of a chamber with inclined nozzles in its cover placed along the direction of movement of the semi-finished product. Coming from the nozzles the compressed air forms an air cushion between the chamber cover and the bearing surface of the material moved by forces of viscous friction and pressure. In this case occurring of such phenomena as friction of the bearing surfaces of the semi-finished product and the conveyor is excluded. However, due to a sharp increase in the speed of the product movement the necessity to reduce it can arise.

Jet pneumatic conveyors of an open type can be used for SM sheet material moving on the air cushion with different strength indicators and physical and mechanical characteristics. Due to this fact it is able to exclude motion detrition of functional surfaces of the sheet and the conveyor.

For example, in accordance with ISO standards, one or multilayered cardboard material can be used for cutting without counter knife applying. In the sheet piecedriver the thickness of the sheet can reach more than $0.25 \mathrm{~mm}$ with a minimum mass of $224 \mathrm{~g} / \mathrm{m}^{2}$. Taking into account the type of production, that is a paper-based package in our case, one or multi- layer hard card material with relatively high indicator of hardness will be the most fitted choice for mentioned above method of cutting.

The operation principle of the method for the sheet material trimming without use of the counter-knife involves the following steps (fig. 1). Sheet material (SM) 1 is driven into the processing zone by means of upper and lower pass conveyors 2 . When the SM appears on the horizontal table 3, it is held by two guides 4 on its top. In the cutting zone, the knife blade 5 fixed on the base of the rotating drum 6, cuts the semi-finished product, and during its transporting simultaneously receives the compressed air resistance from the pneumocounter-knife 7 . The sheet cut in accordance with the given curvilinear geometry is removed by the output conveyors 8 .

The pneumo counter-knife module 7 consists of a chamber and nozzles. In the chamber through the connecting pipe (in the figure it is not shown) the compressor is applied that supplies compressed air. The chamber is made in the form of a welded structure prevented the loss of compressed air. It is supposed to use the following geometric dimensions of pneumo counter-knife module for A4 sheet size: height $(\mathrm{h})-60 \mathrm{~mm}$, width (a) $-74 \mathrm{~mm}$, length (b) $-214 \mathrm{~mm}$, wall thickness (d) $-0,5 \mathrm{~mm}$.

The method of continuous transportation of SM using pneumo counter-knife module can be effective under the given conditions. So, for SM trimming during its transportation, we need relatively small indicators of its density and a relatively large surface of its flow. Quantitative evaluation of 
these characteristics is determined using coefficients $\sigma_{1}=\frac{\omega_{c}}{m}$ and $\sigma_{1}=\frac{\omega_{\mathrm{n}}}{\mathrm{m}}$ (where $\omega_{\mathrm{c}}, \omega_{\mathrm{n}}-$ the area of the midsection and the surface of flow, $m$ - the mass of the product). With the help of these indicators, we determine the necessary magnitude of the SM airresistance during its air flow (the value of the pressure forces $\mathrm{F}_{\mathrm{T}}$ ) and the magnitude of the viscous frictional forces $F_{\tau}[7]$.

It should be noted that the horizontal movement of SM is affected by the symmetrical distribution of compressed air along the $z$ axis. Based on this condition, we use as an example the law of air pressure distribution for a nonlinear geometric shape material:

$$
\begin{aligned}
& p=p_{a}+\frac{G}{\pi \cdot R^{2}}+ \\
& +\frac{3 \mu \cdot U_{0} \sin (\alpha)}{2 \cdot h^{3}} . \\
& \cdot\left(R^{2}-4 x^{2}\right) .
\end{aligned}
$$

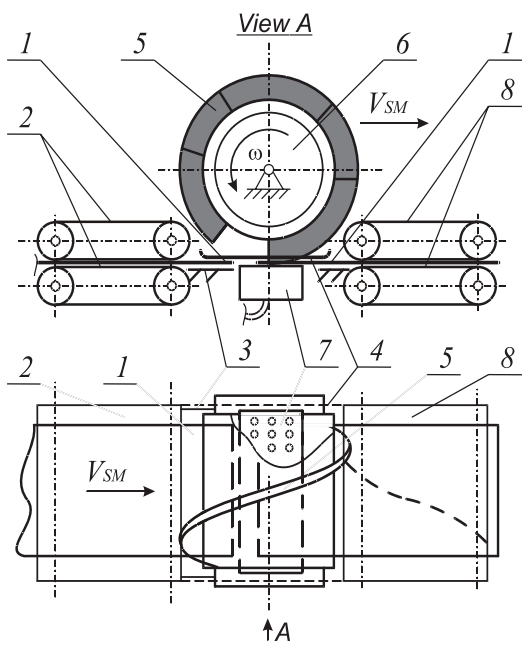

Fig. 1. Technological scheme without using counter-knife method of SM cutting
Using this relation, we determine the flow rate of the compressed air outflow from the nozzles to the pneumocounter-knife module. It is accepted that $p=p_{a}$ at $x= \pm R$. Accordinly $U_{0}$ :

$$
U_{0}=\frac{2 G \cdot h^{3}}{9 \pi \cdot R^{4} \mu \sin (\alpha)},
$$

where $\mathrm{h}$ - the height of the accent of the product on the air cushion; $\mu=v \rho, v-$ dynamic and kinematic viscosity coefficient; $\rho$ density of air; $\alpha-$ the tilt angle of the nozzles to the horizontal.

For the straight-line shape of the product, formula (1) takes the form:

$$
\begin{aligned}
& p=p_{a}+\frac{G}{\pi \cdot R^{2}}+ \\
& +\frac{3 \mu \cdot U_{0} \sin (\alpha)}{2 \cdot h^{3}} . \\
& \cdot\left(1^{2}-12 x^{2}\right) .
\end{aligned}
$$

And, accordingly, the flow rate of compressed air outflow from pneumocounter-knife module nozzles will be:

$$
U_{0}=\frac{2 \cdot G \cdot h^{3}}{l^{3} \cdot b \cdot \mu \cdot \sin (\alpha)},
$$

where I, b - respectively, the length and width of the SM.

Such forces act on the sheet material: the viscous friction force $\vec{F}_{\tau}$, the jet flow force on the end plane $\vec{F}_{k}$, force of resistance to movement $\vec{R}$, the gravity force $\vec{G}$ and the vertical component of the airflow pressure $\vec{N}$. Under the 
condition of balance for AM retention on so-called air cushion, we

have the condition $\overrightarrow{\mathrm{G}}-\overrightarrow{\mathrm{N}}=0$.

The main parameters of the cutting process using pneumocounter-knife module are air flow $Q$, nozzle radiusand number of nozzles $\mathrm{N}$. The total air flow can be determined:

$$
\begin{aligned}
& Q=\mu_{0} \cdot N \cdot \pi . \\
& r^{2} U_{0} \sin (\alpha),
\end{aligned}
$$

where $\mu_{0}-$ the coefficient of compressed air consumption.

In order to keep steadily the sheet by the air flow, it is necessary to provide the condition for of the constant supplying of compressed air. Therefore, we determine the radius of the nozzles $r$ by the formula:

$$
\begin{aligned}
& r=\frac{2 \cdot h^{2}}{3 \cdot \pi \cdot R} . \\
& \sqrt[3]{\frac{G \cdot \rho}{9 \cdot \mu_{0}^{2} \cdot \mu^{2}}} .
\end{aligned}
$$

We determine the number of nozzles $\mathrm{N}$ on the assumption of statement that the stability of the horizontal SM motion with given weight $G$ occurs if in each row the number of nozzles below it is greater than three, i.e. $\frac{N}{2 \cdot L} \cdot I \geq 3$ where $\mathrm{I}-$ the length of the transporting $\mathrm{SM}$. We formulate the last inequality in terms of the number of nozzles per unit of length of the conveyor $L$, i.e. $n=\frac{N}{L} \geq \frac{6}{l}$. Given the limits on the total quantity of the nozzle diameters, we assume that the length of the AM is larger than the sum of the nozzle diameters under it by a factor of six, i.e. $n \leq \frac{1}{6 \cdot r}$. From herewe get: $\frac{6}{1} \leq n \leq \frac{1}{6 \cdot r}$.

Thus, we construct the graphs showing the relation of the consumption of compressed air and the diameter of the nozzles $d$ (fig. 2) and the relation of the compressed air consumption on the number of holes $\mathrm{n}$ for the selected diameter $d=3,5 \mathrm{~mm}$ (fig. 3).

In accordance with the graph of the relation of the compressed air consumption (fig. 2), it can be concluded that the diameter of the nozzle holes increases with proportional increasing of the air flow. Thus, in the interval from $2 \mathrm{~mm}$ to $4.5 \mathrm{~mm}$, we observe a proportional and uniform consumption of compressed air in the range from $0,025 \mathrm{~m}^{3} / \mathrm{s}$ to $0,048 \mathrm{~m}^{3} / \mathrm{s}$. And using the selected holes in the segment of $4.5 \mathrm{~mm}$ or more an increase in costs $Q$ ranging from $0,05 \mathrm{~m}^{3} / \mathrm{s}$ to $0,2 \mathrm{~m}^{3} / \mathrm{s}$ occurs. That is, there is a sharp increase in compressed air to $82 \%$ can be observed.

The same trend is shown on the relation of the air flow and the number of holes $\mathrm{n}$ for the chosen diameter $\mathrm{d}=3.5 \mathrm{~mm}$ graph (fig. 3).With an increase in the number of holes $n$ (ranging from 10 to 30 ) with the selected $d$, we can see a relatively steady growth $Q$ from $0,08 \mathrm{~m}^{3} / \mathrm{s}$ to $0,22 \mathrm{~m}^{3} / \mathrm{s}$.

\section{Conclusions}

The advantage of the method of sheet material trimming without counter-knife applying is the excluding of dynamic forces action that arise in the zone of technological process completion. Without 
using counter-knife trimming method greatly simplifies the interoperations processes in the flowline production. Sheet material is undergone by slight deformations, that, consequently, felicitates the quality of the cutting process. The sheet material keeping on the so- called air cushion in the processing zone excludes the contact of the cutting tool with the traditional counter-knife. Given that the knife blade contacts directly only with the semi-finished product, it can be stated that its dulling is minimized.

\section{Список використаної літератури}

1. Хведчин Ю. Й. Деякі питання механіки різання стосів клиноподібним ножем / Ю. Й. Хведчин // Поліграфія і видавнича справа. Львів: УАД, 2003. Вип. 40. С. 37-43.

2. Регей І. І. Наукові основи розроблення енергоощадної технології і засобів виготовлення розгорток картонного паковання [Текст]: дис. д-ра техн. наук: 05.05.01 / І. І. Регей. Львів, 2007. 269 с.

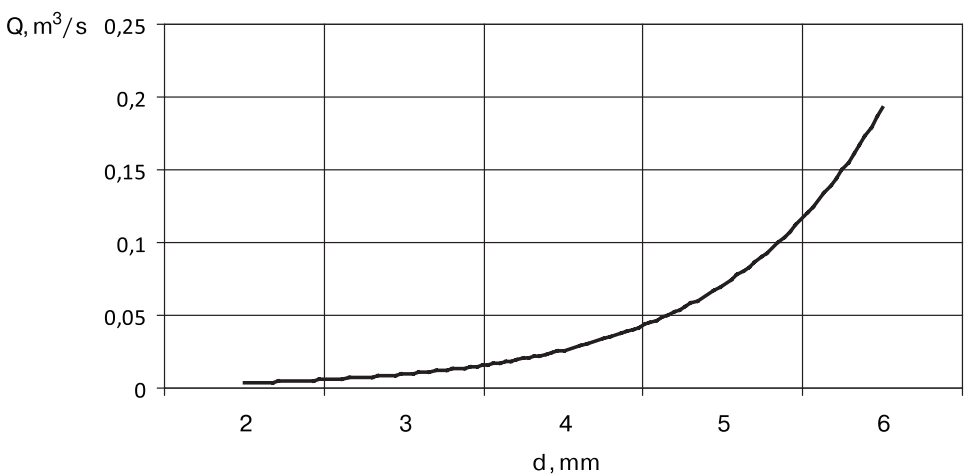

Fig. 2. Relation of the flow of compressed air and the diameters of the nozzles $d$

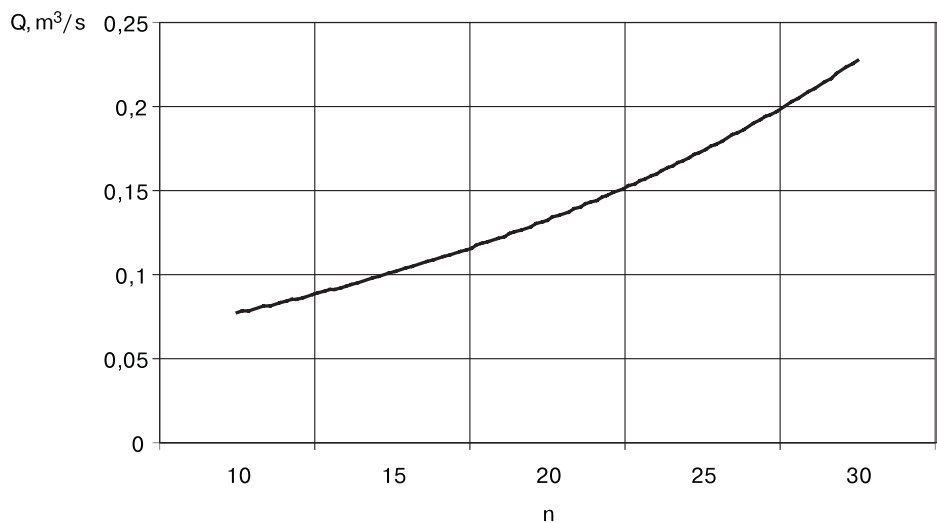

Fig. 3. Relation of air flow and the number of holes $\mathrm{n}$ in the selected diameter $\mathrm{d}=3.5 \mathrm{~mm}$ 
3. Задра В. М. Комплексна оптимізація засобів для прорізування різнопрофільних отворів у паперово-картонних виробах [Текст]: дис. канд. техн. наук: 05.05.01 / В. М. Задра. Львів, 2003. 177 с.

4. Пат. України на корисну модель № 98846. B31B1/14, B26D1/00. Пристрій для підготовки картонних боковинок фігурної палітурки / А. І. Іванко, Ю. О. Шостачук. Заявл. 19.11.2014; Опубл. 12.05.2015. Бюл. № 9, 2015. 4 с.

5. Іванко А. І. Пристрій для фігурного обрізування аркушевих матеріалів в потокових лініях / А. І. Іванко, С. Л. Панов // Технологія і техніка друкарства. Київ: ВПІ НТУУ «КПІ», 2015. Вип. 4(50). С. 105-110. Режим доступу: http://ttdruk.vpi.kpi.ua/article/view/54334.

6. Іванко А. І. Обрізування аркушевих матеріалів у пневматичних транспортувальних системах / А. І. Іванко, О. С. Марченко // Технологія і техніка друкарства. Київ: НТУу «КПІ», 2016. Вип. 2(52). С. 72-78. Режим доступу: http://ttdruk.vpi.kpi.ua/article/view/71012.

7. Проць Я. І. Дослідження конструкцій струменевих живильників листового матеріалу / Я. І. Проць, П. С. Федорів, Ю. О. Цяпута, В. В. Скочиляс // Технологія і техніка друкарства. Київ: НТУУ «КП|», 2012. Вип. 1(35). С. 123-129. Режим доступу: http://ttdruk.vpi.kpi.ua/article/view/32760.

\section{References}

1. Khvedchyn, lu. I. (2003). Deiaki pytannia mekhaniky rizannia stosiv klynopodibnym nozhem [Some questions of the mechanics of cutting of planks with a wedge-shaped knife]. Journal of Polihrafiia i vydavnycha sprava, 40, 37-43. Lviv: UAD [in Ukrainian].

2. Rehei, I. I. (2007). Naukovi osnovy rozroblennia enerhooshchadnoi tekhnolohii i zasobiv vyhotovlennia rozghortok kartonnoho pakovannia [Scientific bases of development of energy-saving technology and means of manufacturing of cardboard packing]. Lviv, 269 [in Ukrainian].

3. Zadra, V. M. (2003). Kompleksna optymizatsiia zasobiv dlia prorizuvannia riznoprofilnykh otvoriv u paperovo-kartonnykh vyrobakh [Comprehensive optimization of tools for cutting various-profile holes in paper-cardboard products]. Lviv, 177 [in Ukrainian].

4. Ivanko, A. I. \& Shostachuk, lu. O. Prystrii dlia pidhotovky kartonnykh bokovynok fihurnoi paliturky [Device for the preparation of cardboard of side notched cover] // Patent № UA98846. Publish 12.05.2015 [in Ukrainian].

5. Ivanko, A. I. \& Panov, S. L. (2015). Prystrii dlia fihurnoho obrizuvannia arkushevykh materialiv $v$ potokovykh liniiakh [Mechanism for curvilinear cut sheet material in the production line]. Journal of Tekhnolohiia i tekhnika drukarstva - Technology and Technique of Typography, 4(50), 105-110. Retrieved from http://ttdruk.vpi.kpi.ua/article/view/54334 [in Ukrainian].

6. Ivanko, A. I. \& Marchenko, O. S. (2016). Obrizuvannia arkushevykh materialiv u pnevmatychnykh transportuvalnykh systemakh [Cutting of sheet materials in pneumatic conveying systems]. Journal of Tekhnolohiia i tekhnika drukarstva - Technology and Technique of Typography, 2(52), 72-78. Retrieved from http://ttdruk.vpi.kpi.ua/article/view/71012 [in Ukrainian].

7. Prots, la. I., Fedoriv, P. S., Tsiaputa, lu. O. \& Skochylias, V. V. (2012). Doslidzhennia konstruktsii strumenevykh zhyvylnykiv lystovoho materialu [Study of constructions of air-jet feeders for sheet materials]. Journal of Tekhnolohiia 
i tekhnika drukarstva - Technology and Technique of Typography, 1(35), 123-129. Retrieved from http://ttdruk.vpi.kpi.ua/article/view/32760 [in Ukrainian].

\section{У статті розглянуто систему безмарзанного способу обрізки аркушевого матеріалу.}

Ключові слова: аркушевий матеріал; різальний інструмент; обрізування; пневмомарзан; транспортування; зона обробки; повітряна подушка.

В статье рассмотрена система безмарзанного способа обрезки листового материала.

Ключевые слова: листовой материал; резальный инструмент; обрезка; пневмомарзан; транспортировка; зона обработки; воздушная подушка.

Рецензент - О. О. Палюх, к.т.н., доцент, КП ім. Ігоря Сікорського

Надійшла до редакції 17.11.17 